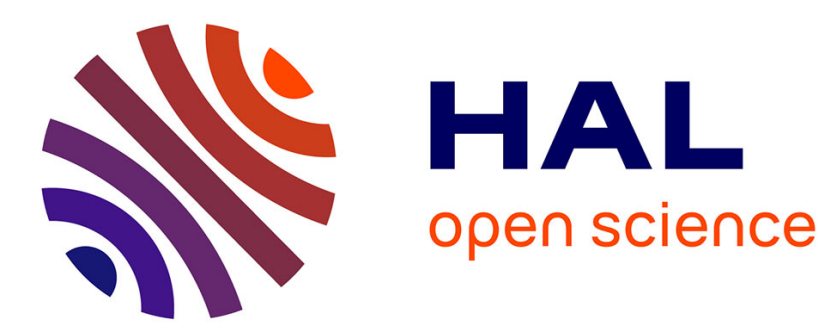

\title{
IONIC CONDUCTIVITY OF YTTRIA STABILIZED ZIRCONIA OBTAINED BY SINTERING OF COPRECIPITATED POWDERS
}

\author{
G. de Portu, A. Fiegna, B. Fabbri
}

\section{- To cite this version:}

G. de Portu, A. Fiegna, B. Fabbri. IONIC CONDUCTIVITY OF YTTRIA STABILIZED ZIRCONIA OBTAINED BY SINTERING OF COPRECIPITATED POWDERS. Journal de Physique Colloques, 1986, 47 (C1), pp.C1-777-C1-781. 10.1051/jphyscol:19861118 . jpa-00225514

HAL Id: jpa-00225514 https://hal.science/jpa-00225514

Submitted on 1 Jan 1986

HAL is a multi-disciplinary open access archive for the deposit and dissemination of scientific research documents, whether they are published or not. The documents may come from teaching and research institutions in France or abroad, or from public or private research centers.
L'archive ouverte pluridisciplinaire HAL, est destinée au dépôt et à la diffusion de documents scientifiques de niveau recherche, publiés ou non, émanant des établissements d'enseignement et de recherche français ou étrangers, des laboratoires publics ou privés. 


\title{
IONIC CONDUCTIVITY OF YTTRIA STABILIZED ZIRCONIA OBTAINED BY SINTERING OF COPRECIPITATED POWDERS
}

\author{
G. DE PORTU, A. FIEGNA and B. FABBRI \\ C.N.R., Research Institute for Ceramics Technology, Via \\ Granarolo 64, I-48018 Faenza, Italy
}

\begin{abstract}
Résumé - Des poudres très fines, pures et réactives de $\mathrm{ZrO}_{2}-\mathrm{Y}_{2} \mathrm{O}_{3}(6.5 \mathrm{M} \%)$ ont été préparées par la méthode de la coprécipitation. Avec ces poudres on a obtenu, après frittage à $1300^{\circ} \mathrm{C}$, de 1 a zirone totalement stabilisée à 1 'oxyde d'yttrium. Ce composé possède une très bonne conductibilité ionique à cause de la faible résistivité intergranulaire. Un tracé d'Arrhenius a permis de dégager deux types de comportements.

Abstract - Very fine, pure and reactive $\mathrm{ZrO}_{2}-\mathrm{Y}_{2} \mathrm{O}_{3}(6.5 \mathrm{M} \%)$ powder was prepared by coprecipitation method. With this powder a dense Y-FSZ was obtained by sintering at $1300^{\circ} \mathrm{C}$. This material showed very good ionic conductivity owing to low intergranular resistivity. Two different trends in the Arrhenius plot were pointed out.
\end{abstract}

\section{I - INTRODUCTION}

Yttria-Fully Stabilized Zirconia (Y-FSZ) was extensively examined//1-4/ as solid electrolyte for high temperature electrochemical devices, owing to its good ionic conductivity. I.t is commonly accepted that this conduction comes from the mobility of oxygen ions associated with structure defects of oxygen ion vacancies shown by $\mathrm{V}-\mathrm{FSZ}$. This material is preferred to Mg0 or Ca0-stabilized zirconia ceramics because they decompose to monoclinic simmmetry after prolonged heating at low temperature. Both grain boundary and bulk resistivity affect the conductivity of the material and the separation of the two components can be achieved experimentality by complex electrical impedance analysis. Grain boundary resistivity is often higher for inhomogeneous materials; it increases with the level of impurities located in that region $/ 5 /$ and with porosity /6/ and it decreases with increasing in the grain size /7/. The coprecipitation method is an interesting route to obtain very pure, fine and homogeneous powders, free from hard aglomerates assuring suitable microstructure and high density after firing at low temperature $\left(1300^{\circ} \mathrm{C}\right) / 8 \%$

The aim of this work was to prepare high purity dense Y-FSZ at low temperature by coprecipitated powders and to measure the electrical conductivity of that material in order to verify how the procedure and the related microstructure affect the parameters considered. 
II - MATERIALS AND METHODS

Powder preparation and sintering

A coprecipitation method $19,10 /$ was used to prepare $Y_{2} O_{3}(6.5 \mathrm{M} \%$ ) stabilized zir-

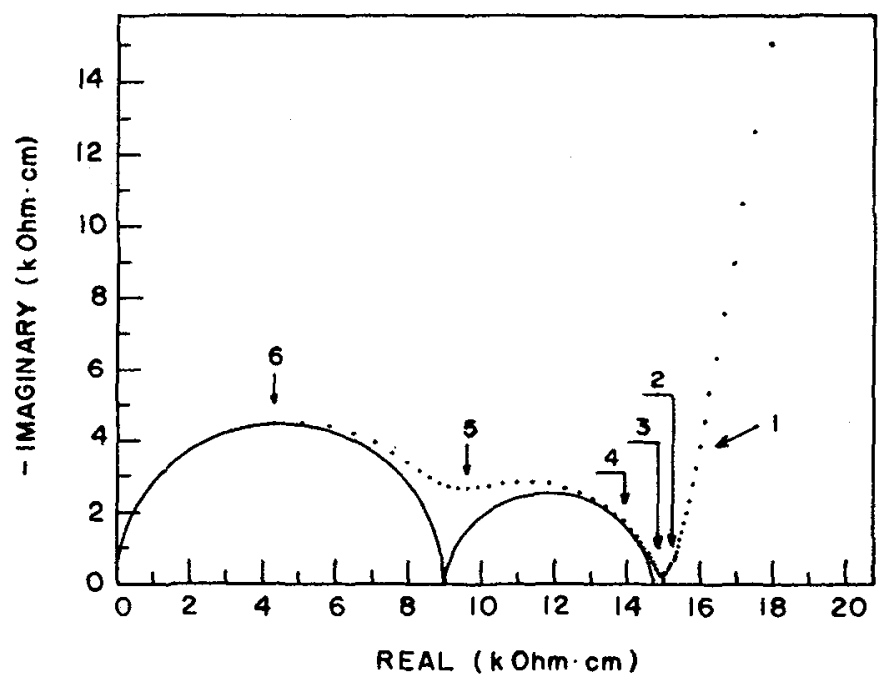

Fig. 1 - Impedance diagram of sintered material showing the "geometric" resistivity (first semicircle) and the grain boundary resistivity (second semicircle) at $400^{\circ} \mathrm{C}$. The labels on the graph are the logarithm of the frequencies.

conia powder. For this purpose the three following aqueous solutions were prepared:

1) $3.46 \mathrm{~g}$ of zirconium chloride $\left(\mathrm{ZrCl}_{4}\right)$ in $200 \mathrm{ml}$ of water;

2) $6.54 \mathrm{~g}$ of hydrated yttrium chloride $\left(\mathrm{YCl}_{3} .6 \mathrm{H}_{2} \mathrm{O}\right)$ in $100 \mathrm{ml}$ of water;

3) about $120 \mathrm{ml}$ of $6 \mathrm{M}$ ammonium hydroxide $\left(\mathrm{NH}_{4} \mathrm{OH}^{2}\right.$.

Analytical-reagent grade products and doubly distilled water were always used. Owing to its highly exothermal reaction, the dissolution of zirconium chioride was made by pouring out the powder slowly into water which was continuously cooled. After that,yttrium solution was poured into zirconium solution and the mixture obtained into the ammonium hydroxide. Immediately an amorphous precipitate, with a volume close to the total volume of the solution, was formed. The mixture was alternatively centrifuged and washed; centrifugation was carried out at about 5000 revs per minute for 15 minutes; finally the slurry was washed four times with water followed by two washings with ethyl alcohol, dried at $120^{\circ} \mathrm{C}$ for at least 24 hours and then calcined at $500^{\circ} \mathrm{C}$ for 30 minutes. After milling, a very fine, homogeneous and pure powder with a surface area of $96.8 \mathrm{~m} / \mathrm{g}$ (average diameter about $10 \mathrm{~nm}$ ) was obtained. X-ray analys is showed a powder consisting of mixed zirconium and yttrium oxide.Cylindrical samples (diameter about $25 \mathrm{~mm}$, thickness about $3 \mathrm{~mm}$ ) were prepared by dry pressing this powder at about $196 \mathrm{MPa}$. The green density was $2.2 \mathrm{~g} / \mathrm{cm}^{3}(37 \%$ referred to a theoretical density of $5.99 \mathrm{~g} / \mathrm{cm}^{3}$ ). The firing temperature was $1300^{\circ} \mathrm{C}$ for 3 hours with heating rate of about $10^{\circ} \mathrm{C} / \mathrm{min}$ and the final density of the sintered bodies was about $5.70 \mathrm{~g} / \mathrm{cm}^{3}(95 \%)$. 


\begin{tabular}{|c|c|c|c|}
\hline$T$ & $\begin{array}{c}R_{b} \\
(0 \mathrm{om} c m)\end{array}$ & $\begin{array}{c}R_{g b} \\
(0 \mathrm{hm} \mathrm{cm})\end{array}$ & $R_{b} / R_{g b}$ \\
\hline 400 & 9090 & 5990 & 1.52 \\
800 & 66.20 & 15.80 & 4.19 \\
1200 & 38.24 & 3.98 & 9.61 \\
\hline
\end{tabular}

Table 1 - Bulk resistivity $\left(R_{b}\right)$, grain boundary resistivity $\left(R_{g b}\right)$ and their ratio as a function of the most significant temperatures.

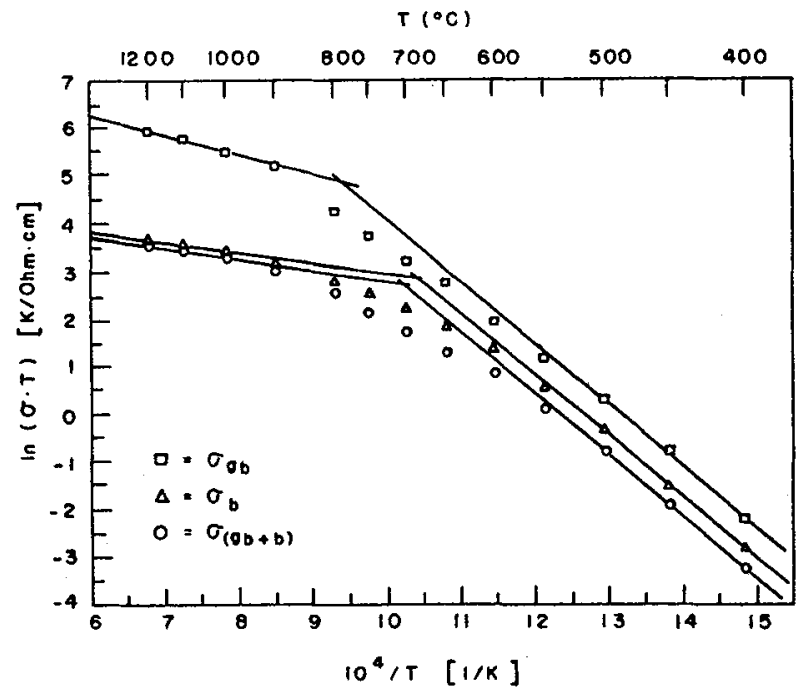
Fig. 2 - Arrhenius plots of the grain boundary $\left[\sigma_{g b}\right]$, bulk $\left[\sigma_{b}\right]$ and total $\left[\sigma_{(g b+b)}\right]$
conductivity.

\section{Complex electrical impedance measurement}

Complex electrical impedance measurements were carried out in air on sintered discs (diameter about $20 \mathrm{~mm}$, thickness about $2 \mathrm{~mm}$ ) in the range from $0.1 \mathrm{~Hz}$ to $1 \mathrm{MHz}$ between 400 and $1200^{\circ} \mathrm{C}$ with very good reliability. The apparatus used was a Frequency Reponse Analyzer (Solartron mod. 1174) interfaced with a personal computer (H-P 85) and a plotter (H-P 7225). Using an appropriate program studied on purpose (Fiegna, A., unpublished work) it was possible to separate the contribution of the parasitic impedances of the system from the experimental data and to keep the potential difference at the electrodes constant $(20 \pm 0.5 \mathrm{mV})$ : the last one was obtained independently from the value of the cell impedance. The two faces of each specimen were polished and coated with a platinum conductive paste $(*)$. The electrical contacts were obtained by platinum wires glued on the two surfaces of the disc.

(*) EngeThard/Hanovia Brushing Platinum Paste 6082. 

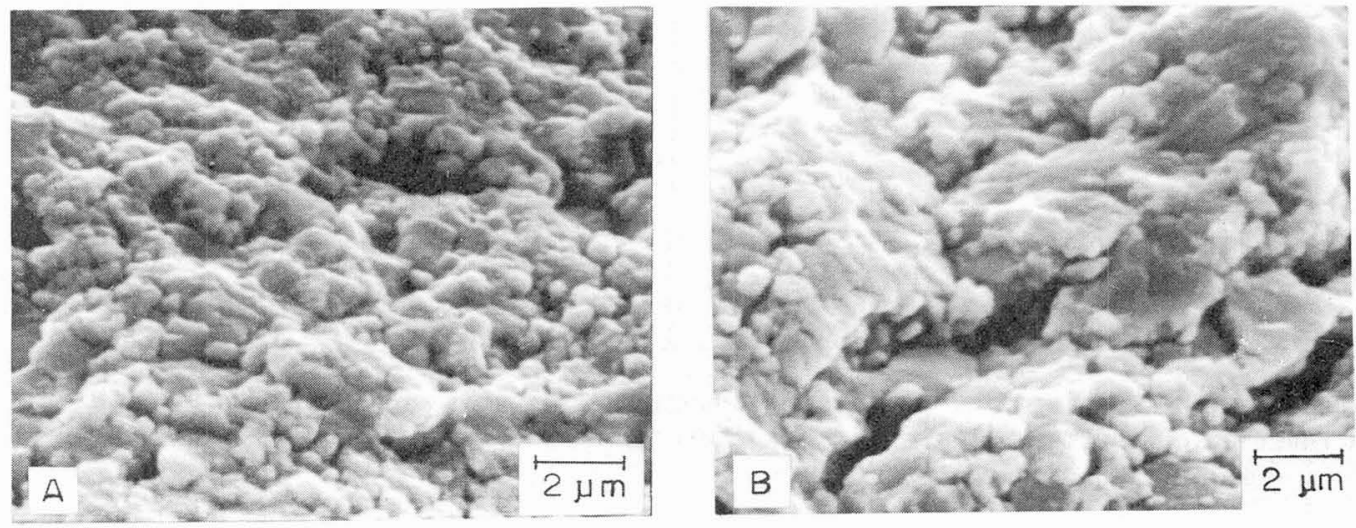

Fig. 3 - Microstructure of fracture surface of sintered material with very fine and homogeneous grain distribution (A) and presence of some agglomerates (B).

\section{III - RESULTS AND DISCUSSION}

Figure 1 shows a typical trend (Nyquist plot) of the complex electrical impedance at $400^{\circ} \mathrm{C}$. The bulk resistivity $\left(R_{b}\right)$ and the grain boundary resistivity $\left(R_{g b}\right)$ were calculated as a function of the temperature using the electrical model previously reported in 1 iterature $/ 11 \%$. The results referred to the most significant temperatures are summarized in Table 1. It $c a n$ be seen that the grain boundary resistivity decreases with the temperature more quickly than the bulk resistivity. In term of conductivity this means that at high temperature the bulk charge transfer mechanism dominates the process. The bulk resistivity is always higher than the grain boundary resistivity. This confirms the results reported by Badwal $/ 12 \%$, who found that the grain boundary resistivity is relatively smalT in pure crystalline material. The Arrhenius plots obtained using the grain boundary $\left(\sigma_{\text {gh }}\right)$, bulk $\left(\sigma_{\text {p }}\right)$ and total conductivity $\sigma_{(g b+b)}$ are reported in Figure 2. As expected from the theory $113 \%$, the Arrhenius $9 \mathrm{p}_{0}$ ts clearly show two different trends: the first one at low temperature (up to $500^{\circ} \mathrm{C}$ ) displaying an activation energy of $107.4,105.5$ and $106.2 \mathrm{kJmol}^{-1} \mathrm{~K}^{-1}\left(E_{\mathrm{gb}}, \mathrm{E}_{\mathrm{b}}\right.$ and $\mathrm{E}_{(\mathrm{ab}+\mathrm{b})}$ respectively) and the second one at high temperature (above $900{ }^{g} \mathrm{C}$ ), referring to an activation energy of $34.0,17.4$ and $19.2 \mathrm{kJmol}^{-1} \mathrm{~K}^{-1}$ ( $\mathrm{E}_{\mathrm{gb}}, \mathrm{E}_{\mathrm{b}}$ and $\mathrm{E}_{(\mathrm{gb}+\mathrm{b})}$ respectively). Nevertheless in this case the break point $\left(\mathrm{gb}_{70}{ }^{\circ} \mathrm{C}\right)$ does not correspond to the eutectoid temperature of $600{ }^{\circ} \mathrm{C}$, reported in Ref./13/. This means that the change in the activation energy cuold be due to a more complex phenomena than the crystallographic transformation suggested in Ref./13/. The meaning of this behaviour is yet unclear and it is difficult to find a definitive explanation, so further investigations should be useful.

As pointed out before, in general, the grain boundary resistivity increases with a decrease in the grain size and an increase in the porosity and impurities. In this case the low grain boundary resistivity means that the small grain size of our material (Fig. 3A) is largely compensated by the high density obtained and the high purity level of the powder. Even if an exaggerated grain growth can be some times observed (Fig. 3B), the method used is useful to obtain a suitable microstructure. 
IV - CONCLUSION

Using a coprecipitated powder we achieved a dense $\mathrm{Y}-\mathrm{FSZ}$, sintered at relatively low temperature $\left(i 300^{\circ} \mathrm{C}\right)$, with good ionic conductivity and suitable microstructure. Two different activation energies for the charge transfer mechanism, in the range of temperature $400-1200^{\circ} \mathrm{C}$, have been confirmed: the first one, at low temperature, depends on microstructure and secondary phase composition, while at high temperature the conductivity (mainly bulk conductivity) could be related to some lattice or vacancies concentration modification.

\section{REFERENCES}

/1/ Radford, K.C. and Bratton,R.J., J. Mat. Sci. 14 (1979) 59.

/2/ Pascual, C., Jurado, C. and Duran,P.,J. Mat. Sci. 18 (1983) 1315.

/3/ Kuwabara, M., Murakami, T., Ashizuka, M., Kubota, $\bar{Y}$. and Tsukidate, T., J. Mat.

Sci Letters 4 (1985) 467.

/4/ Badwa T, S.P.S. and Swain, M.V., J. Mat. Sci. Letters 4 (1985) 487.

/5/ Verkerk, M.J., Winnubst, A.J.A. and Burggraaf, A.J., J. Mat. Sci. 17 (1982) 3113.

16/ Inozemtsev, M.V., Perfil'ev, M.V. and Lipilin, A.S., Elektrokhimiya 10 (1974) 1471 .

17/ Verkerk, M.J., Middlehuis, B.J. and Burggraaf, A.J., Solid State Ionic 6 (1982) 159.

/8/ Brook, R.J., Proceedings of the First International Conference on "Science and Technology of Zirconia". Case Western University, Cleveland OH., Advances in Ceramics 3, edited by Amer. Ceram. Soc. (1981) pp. 272.

/9/ Haberko, K., Ceramurgia Int. 5 (1979) 148.

/10/ Haberko, K., Ciesla, A. and Pron, A., Ceramurgia Int. 1 (1975) 111.

$111 /$ Winnubst, A.J.A., Verkerk, M.J. and Burggraaf, A.J., in "Additives and Interfa= ces in Electronic Ceramics", The Amer. Ceram. Soc. (1983) Vol. 7 pp. 177.

/12/ Badwal, S.P.S., J. Mat. Sci. 19 (1984) 1776.

/13/ Moghadam, F.K., Yamashita, T. and Stevenson, D.A., as Ref./8/ pp. 364. 